\title{
TWO NEW AFRICAN SPECIES OF CTENOPHTHALMUS (SIPHONAPTERA).
}

\author{
BY DR. KARL JORDAN.
}

(With text-figures 1 to 4 .)

\section{Ctenophthalmus evidens (text-figs. $1 \hat{\jmath}, 3$ ㅇ) .}

oㅇ․ Close to Ct. atomus J. \& R. 1913 from Angola, of which only one $q$ is known. The $q$ of the new species differs from that specimen in the shape of sternites VII and VIII.

Comb of pronotum with 16 spines. On mesonotum (apart from the basal bristles) 2 rows, and in front of them some dorsal bristles, in one specimen also

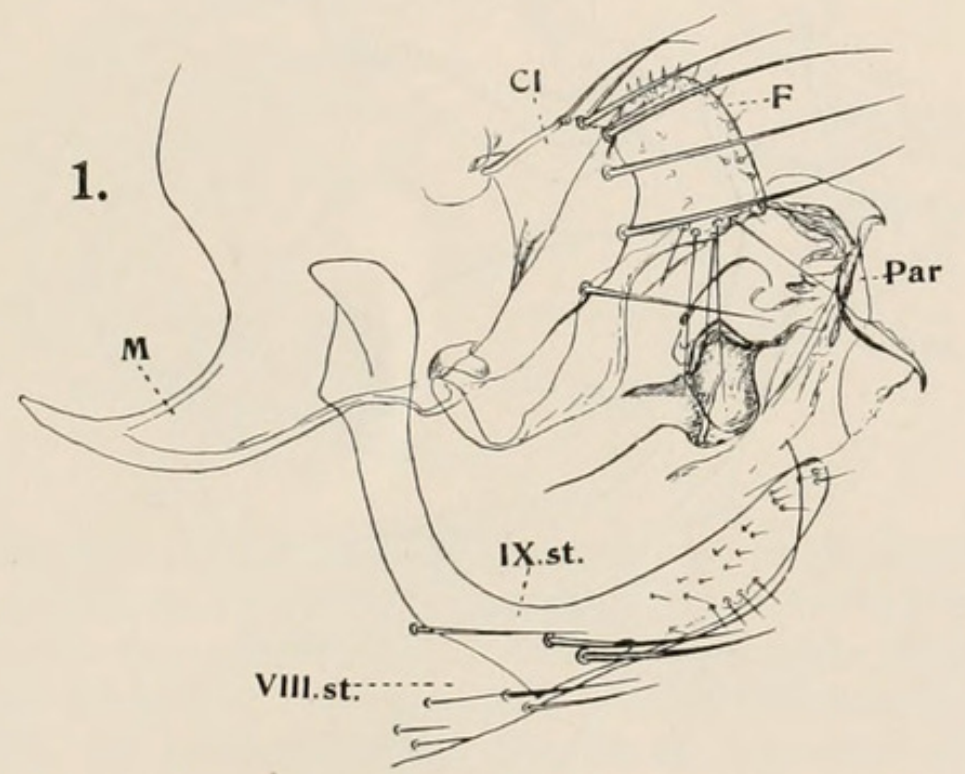

a lateral one representing a third row. Mesopleura with 7 long bristles, metepimerum with 6 or $7(3$ or 4,3$)$; dorso-ventral ridges on lower area of metepimerum not so numerous as in Ct. atomus. In middle of side of basal abdominal sternite the ridges strongly arched backwards, particularly in $q$, recalling Ct. lycosius J. \& R. 1913 and $C t$. moratus Jord. 1926.

o. On VIII. t. a few small bristles above stigma, on VIII. st. 8 or 9 bristles on each side, of which 3 longish ones form a posterior row. Clasper (Cl) apically rounded-truncate, feebly incurved, with a row of 6 long bristles along the margin and near the upper angle a long and a short marginal bristle. Exopodite F dorso-apically strongly rounded, anterior margin nearly straight, posterior margin deeply incurved in middle, apical posterior angle slightly projecting, more rounded in one exopodite than in the other, at the angle a thin bristle, below it 5, of which 4 are long but thin, along dorsal and distal margins a row of 9 or 10 short pale spiniform bristles. Ventral arm of IX. st. not much shorter than vertical arm, slightly turned up, dorsal margin incurved, ventral margin excurved, apex rounded, more so ventrally than dorsally, slightly narrower than middle, on inner side about 21 small thin bristles, of which 2 are apical and 6 or 
7 subventral. Paramere (Par) of penis apically with a dorsal and a ventral hook (lateral aspect).— row of 10 to 12 bristles and in front of the row 9 to 12 ; apex deeply sinuate below middle, the upper lobe broad, truncate-emarginate, its upper angle more rounded than the lower and less strongly projecting; ventral lobe (lateral aspect) triangular, not extending so far distad as lateral lobe. On each side of VIII. $t$. 2 or 3 small bristles above stigma, on lower area 10 to 14 bristles, of which two are apical and marginal, on inside 5 to 7 , of which the lower ones are very

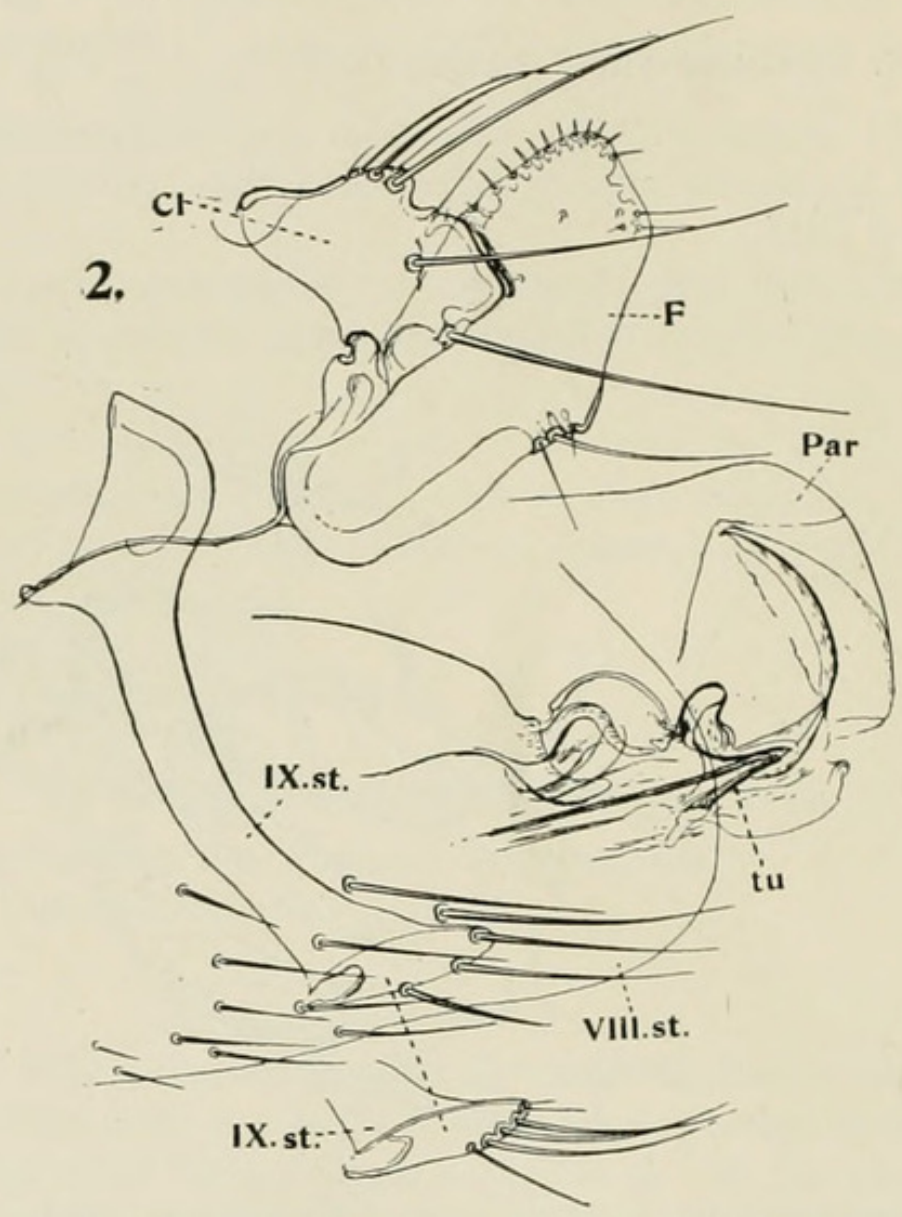

minute, apex rather deeply incurved, lower angle smaller than $90^{\circ}$, upper angle not quite so sharp. Head of spermatheca (R.s.) much longer than tail. Bursa copulatrix together with its duct as long hindtarsal segment III.

Length: $\$ 2.2 \mathrm{~mm}$.; $q 2.3$ to $2.5 \mathrm{~mm}$.—Hindfemur : $0.36 \mathrm{~mm}$.

Hab. Congo Belge: Région Blukwa, Village Tshusa, off Brown Rat (Mission Antipesteuse) ; $1 \hat{\jmath}, 3$ 우 (type in coll. N.C.R.).—I I m much indebted to Dr. H. Schouteden, director of the Congo Museum, Tervueren, for sending me the specimens for study and description.

Among the specimens obtained by the Mission are also $3 \hat{\jmath} \hat{o}$ of Hypsophthalmus campestris J. \& R. 1913 from the same place and off "rats," a species known only from S.W. Uganda and British East Africa.

2. Ctenophthalmus acunus sp. nov. (text-fig. $2 \hat{\jmath}, 4$ f).

ㅇ․ Nearest to Ct. moratus Jord. 1926, from the Gold Coast; differing in the reproductive organs.

o. On each side above stigma of VIII. t. 2 or 3 small bristles, and on 
VIII. st. 14 to 16 , of which the posterior ones are long; clasper nearly as in Ct. moratus, apical margin with a small sinus above middle, at upper angle 5 bristles, of which one very long, 2 shorter and 2 thin and short, on side one long bristle and at ventral margin another, lower a pical angle about $90^{\circ}$. Exopodite $\mathrm{F}$ broader than in $C t$. moratus, dorsally less rounded, the posterior margin from the nose upwards more slanting and less incurved. Ventral arm of IX. st. a little longer than in $C t$. moratus, with 4 ventral bristles, of which the 3 distal ones are long and strong, at apex 2 minute bristles. Apical armature of ejacu-
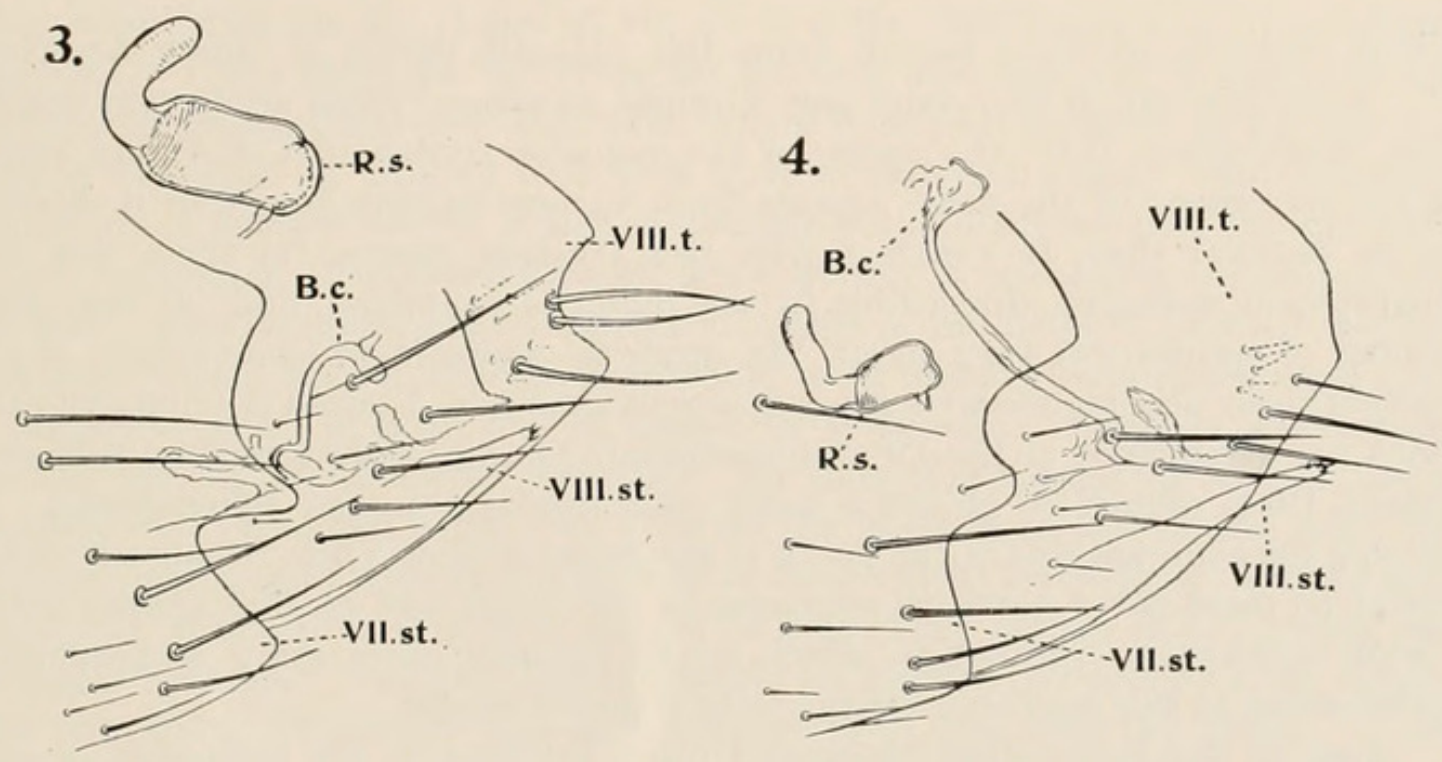

latory duct different : dorsal paramere (Par) without hook, apical tube of duct (tu) short.— - VII. st. : on the two sides together, a posterior row of 10 bristles, and before the row 15 ; apex bisinuate, dorsal lobe broader than median lobe, triangular, angle about $90^{\circ}$, tip rounded off, median lobe rounded, below it the margin straight, not excurved, ventral angle (in side-view) slightly obtuse, rounded off. On each side of VIII. t. above stigma 2 or 3 small bristles, on lower area 10 on left and 14 on right side (we have one specimen !), 5 or 6 of them forming a subventral row, the most distal one short, none at apical margin, lower angle of apex distinct, but obtuse, upper angle effaced, the apical margin being but slightly incurved. Spermatheca of the small type, with the head shorter than the tail. Bursa copulatrix inclusive of its duct a little longer than hindtarsal segment II.

Length: $\hat{2} 2.5 \mathrm{~mm}$.; $q 2.4 \mathrm{~mm}$. Hindtibia : 0.39 to $0.40 \mathrm{~mm}$.

Habi. Nigeria: Lagos, on Bush Rat ; $2 \hat{\jmath} \widehat{o}, 1$ †, received from Dr. G. A. K. Marshall, C.M.G., F.R.S. 


\section{$2 \mathrm{BHL}$ Biodiversity Heritage Library}

1929. "Two new African species of Ctenophthalmus (Siphonaptera)." Novitates zoologicae : a journal of zoology in connection with the Tring Museum 35, 165-167. https://doi.org/10.5962/bhl.part.10823.

View This Item Online: https://www.biodiversitylibrary.org/item/22617

DOI: https://doi.org/10.5962/bhl.part.10823

Permalink: https://www.biodiversitylibrary.org/partpdf/10823

\section{Holding Institution}

Natural History Museum Library, London

\section{Sponsored by}

Natural History Museum Library, London

\section{Copyright \& Reuse}

Copyright Status: In copyright. Digitized with the permission of the rights holder.

Rights Holder: The Trustees of the Natural History Museum, London

License: http://creativecommons.org/licenses/by-nc-sa/4.0/

Rights: http://biodiversitylibrary.org/permissions

This document was created from content at the Biodiversity Heritage Library, the world's largest open access digital library for biodiversity literature and archives. Visit BHL at https://www.biodiversitylibrary.org. 